\title{
Student Disciplinary Challenges in Obuasi Secondary Technical School: The Perspective of Teachers
}

\author{
Beatrice Benewaa* \\ Social Sciences Department, Bia Lamplighter College of Education, Sefwi Debiso, Ghana
}

\begin{abstract}
The purpose of this study was to investigate the disciplinary problems of students in the Obuasi Secondary Technical School from the perspective of teachers. Mixed methods approach was adopted for the study. A sample of 44 teachers was used for the study. Data was collected using questionnaire and an interview guide. The results revealed that truancy/lateness, dress code violation and disrespect for teachers were the major disciplinary problems experienced in Obuasi Secondary Technical School. Again, it was revealed that the major sources of disciplinary problems among students were poor economic background, bad parenting, peer pressure, student's inability to cope with the academic task, inappropriate handling of concerns of students by teachers and authorities and cultural influence. In addition, the study showed that indiscipline acts in schools had adverse impact on both academic and administration work. Finally, the study revealed that punishment was used as a major strategy to deal with disciplinary problems. Punishments have included strategies such as signing bonds of good behaviour and practical performances such as packing dining hall bowls, weeding or sweeping their classroom, internal suspension and external suspensions. It was recommended that schools have a functioning disciplinary committee that sees to cases of indiscipline of students and which should be headed by a trained guidance counsellor.
\end{abstract}

Keywords: Discipline, Indiscipline

DOI: $10.7176 / \mathrm{JEP} / 11-20-16$

Publication date:July $31^{\text {st }} 2020$

\section{Introduction}

Disciplinary issues are matters of concern worldwide. According to Nakpodia (2010), students are priceless assets and most essential elements in education. It is absolutely necessary to direct students to exhibit acceptable attitude and behaviour within and outside the school. In an attempt to achieve an organised and peaceful school environment and maintain law and order, school management specifies rules and regulations to guide the activities of members of the educational organisation. Discipline is readiness or ability to respect authority and observe conventional or established laws of the society or any other organisation. It can also be defined as the means by which children are trained in orderliness, good conduct and the habit of getting the best of themselves (Adesina, 2009; Amoah, Owusu-Mensah, Gyamera, \& Laryea, 2015).

According to Yahaya et al. (2009), discipline is an important element that plays a crucial role in school system, which insists on upholding the moral values of students. Student's discipline is a prerequisite to almost everything a school has to offer students (Seller \& Vornberg, 2002; Nakpodia, 2010). Seifert and Vornberg further link discipline with both the culture and climate of the school, thus, in order for a satisfactory climate to exist within a school, a certain level of discipline must exist.

In schools where discipline is a serious problem, for example, where students bully others, parents can transfer their children to 'better' schools because the well behaved usually perform well (Rigby, 2000; Nakpodia, 2010). Their transfer can affect the overall performance of that school. Troublesome students can sometimes make teachers react emotionally to the extent of using punishment. But punishment, instead of curbing behaviour, can aggravate it (Nakpodia 2010). In the words of McManus (1995) and Nakpodia (2010), punishment does not discourage misbehaviour but rather reinforces the pupils' view of adults as treacherous. As children become adolescents, they experience a variety of physical, emotional and interpersonal changes while simultaneously transitioning from elementary to middle school. If the transition is stressful and the climate of the school appears unwelcoming, low self-esteem, a decline in academic achievement and inappropriate behaviour problems may follow (Kupermine, Leadbeater, Emmons, \& Blatt, 1997; Chair, Chapman, Creighton, \& Twiford, 2007).

In schools where discipline is a serious problem, for example, where students bully others, parents can transfer their children to 'better' schools because the well behaved usually perform well (Rigby, 2000; Nakpodia, 2010). Their transfer can affect the overall performance of that school. Troublesome students can sometimes make 
teachers react emotionally to the extent of using punishment. But punishment, instead of curbing behaviour, can aggravate it (Nakpodia 2010). In the words of McManus (1995) and Nakpodia (2010), punishment does not discourage misbehaviour but rather reinforces the pupils' view of adults as treacherous. As children become adolescents, they experience a variety of physical, emotional and interpersonal changes while simultaneously transitioning from elementary to middle school. If the transition is stressful and the climate of the school appears unwelcoming, low self-esteem, a decline in academic achievement and inappropriate behaviour problems may follow (Kupermine, Leadbeater, Emmons, \& Blatt, 1997; Chair, Chapman, Creighton, \& Twiford, 2007).

The problem of indiscipline in schools is a global issue of great concern, spanning political, economic, geographical, racial and even gender boundaries. There is a growing concern regarding indiscipline in schools within the United Arab Emirates (Agarib, 2006; Kilonzo, 2013), where teaching methods were blamed for the children's indiscipline. The parents were getting anxious and frustrated as they complained of the rising incidences of indiscipline and violence in schools. According to Kilonzo (2013), the schools in Botswana had their image marred by acts of student's indiscipline with some students dying and others becoming blind after they broke into the school science laboratory and consumed toxic amounts of methanol and ethanol.

Research indeed confirms that student disciplinary rates tend to rise at the middle school level (Robers, Kemp, \& Truman, 2013; Theriot \& Dupper, 2010; Mendez, 2003; Liiv, 2015). While it can be argued that this rise is, at some level, simply a normal developmental leap, student misbehaviour in secondary school has far-reaching consequences. Major (1990) and Masekoameng (2010) indicated that there have been incidents involving students calling educators foul names, making obscene gestures when educators tell them what to do, or trying to break up fights.

Acts of indiscipline if allowed to incubate under current favourable conditions by education providers could hatch a monster that will be difficult to exterminate (Idu \& Ojedapo, 2011; Tunor, 2002; Ali, Dada, Isiaka, \& Salmon, 2014). Ultimately, students who are indiscipline frequently spend less time on classwork, and those who are punished more harshly (through exclusionary discipline such as suspension and/or expulsion) also spend less time in the classroom. As a result, these students are at higher risk of school failure and dropout (Mendez, 2003; Arcia, 2006; Corzo \& Contreras, 2011).

In the Ghanaian context, however, there have been numerous reports on the electronic media and other social platforms about the indiscipline behaviour of students and the response of concerned stakeholders to these indiscipline behaviours. Some of these reports have been in recent times and some of the past years. According to a report by the Ghana News Agency (GNA) (2007), the late Alhaji Aliu Mahama, a former Vice President of Ghana during his time as a vice president urged headmasters of Senior High Schools (SHS) in the country to remain fair and firm in enforcing school regulations since there have been increasing reports of students' impunity and disobedience.

In the light of the cases of indiscipline in Ghana, different strategies have been tried by school leaders to manage the menace but to no avail. As such, a GNA report in 2013 revealed that the Conference of Heads of Assisted Secondary Schools (CHASS) advocated for a revision of the Code of Discipline. The heads of the senior high schools in the country indicated that the code of discipline as used at the time had proven to be ineffective. CHASS assured the Ghana Education Service (GES) and the Ministry of Education (MoE) of its commitment to maintain high standards of discipline in schools as a means to achieve quality education. This was after bemoaning the contribution of indiscipline to lowering of the standards of education in the country. In recent times, the Vice-Chancellor of the University of Energy and Natural Resources had advocated a national consultative forum to re-examine the various disciplinary policies and their effective implementation in the nation's educational system (GNA, 2016). The vice chancellor made this claim at the 54th annual meeting of CHASS at Sunyani in 2016, indicating further that this could pave the way to address the pervasive challenge of indiscipline in schools. This report of the GNA further revealed that CHASS was searching into the entry and exit behaviours of students and how that affected their academic performance. The report showed again that the National President of CHASS, Mrs Cecilia Kwakye Cofie, said that CHASS had looked at the current rules and regulations governing students' behaviour and had identified the need for a more credible and workable document that had gone through the drafting stage. This empirical evidence according to the president of CHASS would greatly assist in making informed decisions to address the challenge of indiscipline. This implied that new and different strategies were being searched for in addressing students' indiscipline in senior high schools.

However, in spite of the impact of indiscipline in the education system in Ghana, there appeared to be a few studies carried out on the subject of indiscipline in Obuasi Municipality in Ghana. These studies include that of 
Gyan, Baah-Korang, McCarthy, and McCarthy (2015), Danso (2010) and that of Agyekum, Awudu, Boadu, Buabenmaa and Osei (2011) which sought to explore the issue of indiscipline in the Kumasi Metropolis in Ghana. Danso (2010) highlighted the actual state of indiscipline when he decried the high rates of indiscipline and lawlessness in educational institutions. He revealed further that not a single day passed without a report of an act of indiscipline perpetrated by students in senior high schools and lamented over the causes of drug abuse, rape, armed robbery, abortion and even murder in the educational institutions.

The researcher has observed that the students of Obuasi Secondary Technical School arrive to school late, wander in the school compound during the mid-class, bring mobile phones to school, use their mobile phones in the class while the teachers are teaching, show disobedience and carelessness, bring clothes and other accessories and immediately change after school. The direct observation of the researcher in the teaching profession, specifically in a secondary school, made her realize how disciplinary problems are impacting on educator morale, more so than in the past. Students these days talk as they wish, and are capable of causing a teacher to feel that he or she is unwanted in the classroom. From observations and by means of informal interviews the researcher also became aware that teachers generally experience stress because of students' behaviour. However, there appeared to be no study conducted on indiscipline in the Obuasi Municipality of Ghana. In light of the degree of importance of the subject of indiscipline and the apparent dearth of literature regarding it, the study sought to investigate student's disciplinary challenges experienced by teachers in the Obuasi Secondary Technical School. Specifically, the study aimed at answering the following questions:

1. What are the types of disciplinary problems experienced in Obuasi Secondary Technical School?

2. What are the sources of disciplinary problems that are experienced in Obuasi Secondary Technical School?

3. What is the impact of disciplinary problems on Teacher morale in the Obuasi Secondary Technical School?

4. What coping strategies are adopted by school management in managing disciplinary problems in the Obuasi Secondary Technical School

\section{Literature Review}

\subsection{Social Learning Theory}

The Social learning theory was propounded by Albert Bandura in 1977. The theory can also be called observational learning. Viewing the theory as observational learning reflects the importance of observing other people's behaviour in the learning process. According to Polis and Upenieks (2003), the major premise of this theory is that people do not only learn through their own experiences, but also by observing the actions of others and the results of those actions. This behavioural theory therefore assumes that people learn by observing the behaviours and attitudes of others as well as the outcomes of those behaviours. According to the theory, behaviour can be learnt, relearned and unlearnt. As a result, it is believed by this theory that human beings are the product and producers of their environment (Bandura, 1985; Kiumi, 2012).

Bandura contended that the behavioural habits of children, both good and bad, are developed through observational learning and is referred to as imitation or modelling (Bandura, 1977; Thomas, 2005; Ormrod, 2011). Young students are particularly impressionable and vulnerable and since much of their behaviour is learned and they will copy and act out what they observe to be fashionable and attractive (Feldman, 1996). As a result, an individual's behaviour can be the outcome of modelling.

The theory stresses the importance of children learning through imitation (Ngari, 2014). Therefore, it is safe to associate role modelling that comes from both parents as a learning process for the child. Therefore, how an individual is socialized in a society or community about the norms and practices of the society usually comes from what they observe around them. Children tend to be what it is they see others do (Thomas, 2005; Ormrod, 2008). This is especially true for those who are of a high recognition in society. As a result, children will imitate the behaviours of a parent, teacher, guardian, television character, or peer, often practicing what they observe to receive their individually desired results (Bandura, 1986; McLeod, 2011).

In relation to the study of disciplinary challenges of students, if an individual observes the behaviour of a person he/she regards highly, it is likely that the behaviour will be modelled. This is especially true in the senior high school since students in senior high schools usually behave in a way similar to their friends, particularly popular friends. Again, the kind of home a student comes from can influence the student's tendency to display behaviours that contradict the rules and regulations of the school. This is because if a student comes from a home or society where violence is the means of making your point, it is highly probable that the individual will model that 
behaviour and practice the behaviour in the school environment.

\subsection{The Concept of Discipline}

Discipline as a concept has been viewed differently by several authors in different quarters. Depending on the perspective of the author, a different view was offered. In general, Ouma, Simatwa, and Serem (2013) viewed discipline as the actions by management to enforce organizational standards. In the school situation, Temitayo, Nayaya, and Lukman (2013) defined discipline as the regulation of children and the maintenance of order ("rules") in schools. Temitayo et al. claimed that these rules may delineate the expected standards of clothing, timekeeping, social behaviour and other work ethics. It implies the many standards or codes of behaviour to which teachers, students and non-teaching staff must adhere to.

\subsection{Disciplinary Problems}

Discipline problems have been seen in different ways from different perspectives. Mabeba and Prinsloo (2000) described discipline problems as the disruptive behaviour that significantly affects students' basic rights to feel safe, to be treated with respect and to learn in a more conducive environment. Barasa (2013) also defined indiscipline as the attitude and unwillingness to make efforts required to achieve the objectives in the school system. This makes the student a defiant person who chooses to rebel and turn away from the laid down rules and regulations in the school.

\subsection{Sources of Disciplinary Problems}

Discipline problems have been found to be caused by several factors by several researchers. According to Okumbe (2001), discipline problems among students have their roots in the school, society and in the mind of students. Thus, the causes of indiscipline could be related to student's peculiarities, the social and family context, external influences and of social, economic, cultural, generational nature. Again, the causes could be related to the personality and professionalism of the teacher. Other causes could be related to the school as an organization or the educational system as a whole.

The home factor is also a major cause of discipline problems among students. Farrant (2001) posited that even though most children receive the attention they need at home or in school in normal positive ways, some students feel that misbehaving in class or school is the best way to get attention. These students are the ones who usually speak out when they are called to do so, arrive late or make strange noises which disrupt attention particularly during class (Ntebe, 2006). It appears that the lack of parental involvement is the major cause of disciplinary problems in secondary schools (Temitayo et al., 2013). Parent or home influences on discipline is also seen in several other ways such as single parent homes, a lack of parental control at home, the negative influence of television, neighbourhood and community problems that influence the home, and value differences between the home and the school.

It has been indicated by research that children living in neighbourhoods of concentrated poverty demonstrate trauma symptoms and coping mechanisms that may appear disruptive in schools, such as anxiety, hypervigilance, and presenting a "tough front" to ward off further victimization (Anderson, 1999; Stewart, Schreck, and Simons, 2006). Further, studies have shown that children who grow up in neighborhoods of concentrated poverty not only learn coping mechanisms but also develop an understanding of society and their place in it that may lead to "acting out" behaviours deemed disruptive or counterproductive in schools (Ferguson, 2001; Eaton, 2010). Thus, children from very tough background socially and economically create oppositional identities as "bad boys" to cope and resist in schools. On the basis of these studies, effective school level policies to manage disciplinary problems must also be paired with larger economic and social policies that actualize the promise of equal opportunity. This can help reduce some misbehaviours among students.

Every school administrator is committed to ensuring that school provides a safe and orderly environment in which teaching and learning take place each day (Temitayo et al., 2013). In this regard, the school leadership as well as the environment created in the school can affect the overall behaviour of the students. Absence of effective leadership can result in poor management in the areas of direction, guidance and instructions which can in turn lead to disciplinary problems. A harmonious environment at school increases the chance of students realizing their full educational potential (Temitayo et al., 2013). The reverse of this is true. Again, a lawless school environment promotes disciplinary problems to the school administrators, teachers and in the end affect the performance of the students. Another element in the school environment which is vital to the maintenance of discipline or otherwise in the school environment is the teachers within the school.

\subsection{Types of Discipline Problems}

Several forms of disciplinary have been identified by several researchers. Zubaida (2009) identified forms of 
discipline problems among senior high school students to include truancy, lateness to school, cultism, and drug abuse, insulting/assaulting, stealing and rioting. Some other forms of discipline problems that were identified were shouting, snatching other student's property, bullying, cheating, viewing pornographic materials, and threatening teachers. The study of Onyechi, Okere and Trivellor (2007) also brought to light some discipline problems such as walking out on the teacher, noise making, sleeping in class, immorality and use of drugs in Nigerian schools, Okoson (2010) as cited in Magwa and Ngara (2014) identified act of disciplinary problems to be in the form of truancy, hooliganism, disrespect for school authorities, cheating in examinations and drunkenness.

An investigation carried out by Matseke (2008) revealed that students have lost respect for educators and for the disciplinary rules of the school. This is similar to the report of Rossouw (2003) that students and especially High School students have developed arrogance towards the authority of educators and parents. Rossouw indicated further that this has been exacerbated by the over emphasis on children rights, which has made so many parents failed to instil respect for people of authority in their children at home. As a result, the child could bring this disrespectful attitude to school.

Aside from disrespect towards authority, other disruptive behaviours have been reported by other authors. A study by Martin (2004) showed that disruptive behaviour during class was reported more frequently by teachers and administrators in rural High schools $(21 \%)$ than by teachers and administrators $(17 \%)$ in urban schools. In support of this view, it has been found that one in five boys will result to physical conflict since fighting is believed among students especially boys, to be the best way of resolving conflict situations and so boys regard their peers who do not fight as weaklings (Mokhele,2005).

Truancy and absenteeism are critical issues for every school. It involves irregular attendance in school or classes (Temitayo et al., 2013). Many factors are responsible for students engaging truancy and absenteeism. Some of the factors include peer group influence and methods of teaching or discipline. Teachers may have poor attitude to class teaching by using inappropriate materials and contents in such a manner that may constitute them into a certain source of absent on the part of students as resulting from dissatisfaction and frustration from schoolwork. Again, the leadership of the schools may be responsible for the truancy or absenteeism behaviour of the students.

\subsection{Impact of Disciplinary Challenges}

Discipline problems among student can have several and divers effect on all stake holders in the school system. Finn, Fish and Scott (2008) has cited in Magwa and Ngara (2014) and Oliver (2011) are of the view that when students misbehave they learn less and keep their peers from learning. This is because teaching contact time is reduced and more time is devoted to managing misbehaviour rather than teaching. Finn et al further asserted that this creates stress for teachers when they are detracted from academic time.

Noguera (2003) opined that ineffective classroom management and misbehaviour among students may create difficulties in providing high-quality teaching and learning opportunities. This is because it is difficult to teach when disruptions are occurring continuously throughout the day in the classroom. This was supported by the view of Azizi et al. (2009) that students' misconduct or misbehaviour in the classroom interferes with teaching and learning and is believed to be an antecedent to later school dropout and other similar negative social outcomes. Marzano (2007) have also pointed out that students are unproductive and cannot learn in a classroom that is chaotic and poorly managed.

\subsection{Response to Disciplinary Problems}

In instances of disciplinary problems, several mechanisms can be put in place. One major means is deprivation of privilege as a form of punishment. Temitayo et al. (2013) have indicated that deprivation of privilege is a useful and efficient form of punishment. Exclusion or expulsion is noted as a punishment. With drawing or permanent exclusion is the removal of a pupil permanently from the school. This is the ultimate last resort, when all other methods of discipline have failed. However, in extreme situations, it may also be used for a single offense. Punishment and exclusion in the school setting are used to send strong messages to students that certain behaviours will not be tolerated and also to assure the school community and public at large that order and civility are being maintained and that schools are safe. Skiba and Knesting (2001) therefore opined that the use of zero tolerance policies of punishing disciplinary problems is to ensure that the severe and rigid consequences will deter students from committing acts of severe indiscipline in schools.

\section{Methodology}

The mixed methods research approach was adopted for this study. Specifically, the Explanatory Sequential mixed method design was used for the study. This design was considered appropriate for the study because the 
researcher wanted to expand on the outcome of the quantitative findings by using the qualitative data to get more in-depth understanding of the phenomenon. The study was carried out using a sample of 341 students and 44 teachers from the Obuasi senior high technical school in the Obuasi Municipality. Purposive, stratified and simple random sampling procedures were used for the study. A self-designed questionnaire and a semi-structured interview guide was used for the collection of the data for the study. The data collection instruments were pilot tested before used in the main study. Consideration was also given to ethical issues like consent, anonymity, plagiarism, confidentiality and autonomy. The data collected through the questionnaire was analysed descriptively while the interview data was transcribed and analysed using thematic analysis according to the research questions of the study. The findings were discussed in relation to relevant literature.

\section{Results}

\subsection{Types of Disciplinary Problems in Obuasi Secondary Technical School}

To examine the types of disciplinary problems experienced in Obuasi Secondary Technical School, respondents were requested to indicate the common disciplinary problems that they saw students exhibit in school. The results are depicted in Table 1.

Table 1: Disciplinary problems in the school

\begin{tabular}{lll}
\hline Statements & Frequency & \% \\
\hline There is truancy among students & 21 & 48 \\
Students show insubordination to school authority & 44 & 100 \\
Leaving campus without permission & 40 & 91 \\
Bullying is high among students & 26 & 59 \\
Students always fight among themselves & 40 & 91 \\
Dress code violation & 44 & 100 \\
Class disruption & 36 & 82 \\
Vandalism & 20 & 45 \\
Theft & 42 & 95 \\
\hline
\end{tabular}

Source: Field data

Table 1 reveals the responses of teachers about the types of disciplinary problems experienced in Obuasi Secondary Technical School. From the table, it can be observed that the most frequently selected responses were showing insubordination to school authority (44), representing $100 \%$ and dress code violation (100\%). These were followed by theft which was selected by 42 (95\%) participants. Fight among students was selected by 40 $(91 \%)$ teachers who thought was the major disciplinary problem. Also, students leaving campus without permission was selected by 40 (91\%) out of teachers who participated in the research. Again, 36(82\%) of the participants selected class disruption as a major disciplinary problem of students.

The interview responses highlighted several concerns the types of disciplinary problems have on the school. The following are some typical responses.

Bernice: There are a lot of disciplinary challenges in the school but the rampant ones in my opinion is truancy, thus absenting oneself from classes without any good reason. Indecent dressing which means students put on sandals and shoes which is not prescribed to school and leaving campus without exeat. [32 year old female teacher]

From the responses, one of the major theme which emerges as a disciplinary challenge in the school is lateness on the part of both students and teachers. All the ten participants' revealed that most of the day students report to school late. This is because, most day students give excuses that the distance from their house to the school is far and sometimes they have to walk for hours before they even get a car to school. The students also attributed their lateness to circumstances beyond their control. Another theme that emerges from the data is indecent dressing also emerged as one of the disciplinary problems in the school. It was revealed that wearing tight shorts is commonly found among male students whiles female students also wear short skirts.

Andy: The disciplinary challenges I have observed in the school is stealing, truancy, absenteeism, and minor ones are fighting and bullying. Disciplinary challenges occur mostly between peers, in the adolescence stage. 
Some of them also lack parental control because some of them take care of themselves. The rampant ones are truancy, absenteeism and fighting. [45 year old male teacher]

Crabbe: The disciplinary challenge we have in our school is the lateness of the students to school with regards to the day students, indecent dressing as a result of the current fashion style has made students to dress badly to school. Wearing tight shorts is the order of the day. ... With the improper dressing too students believe that wearing tight dresses is the talk of the day. Now students resort to altering their school uniforms to make them look more appealing. [30 year old male teacher]

\subsection{Sources of disciplinary problems in Obuasi Secondary Technical School}

The teachers were also required to indicate the source of disciplinary problems that are experienced in Obuasi Secondary Technical School. The results are represented in Table 2.

Table 2: Sources of Disciplinary Problems

\begin{tabular}{lll}
\hline Statements & Freq. & \% \\
\hline Poor economic background & 34 & 77 \\
Bad parenting & 40 & 91 \\
Students' inability to cope with academic task & 36 & 82 \\
Peer pressure & 44 & 100 \\
Cultural and societal influences & 39 & 87 \\
Inappropriate handling of students' concerns by teachers & 30 & 68 \\
\hline
\end{tabular}

Source: Field Data

Table 2 reveals that he major sources of disciplinary problems among students were poor economic background $(77 \%)$, bad parenting $(91 \%)$, peer pressure $(100 \%)$, student's inability to cope with the academic task $(82 \%)$, inappropriate handling of concerns of students by teachers and authorities $(68 \%)$ and cultural influence $(87 \%)$.

The interview responses also highlighted some of the reasons why students made such choices as it raises similar issues. Typical interview comments were:

Andy: The sources of these problems in my opinion are the peers. This is so because when they come to form one they are all innocent (green), so most of the problems are not a factor of their entry behaviours but they copy it from their peers though others come and display such behaviours because it's within them. Others are innocent and pick the character from their friends. Peers do this because they find themselves in gangs, and clans like prodigal clan etc. previously group members used to retaliate when members of their groups are punished but it's now decreasing. [A 45 year old male teacher]

Wegyir: Peers contribute to disciplinary challenges because in the boarding house system they have that level of freedom. They copy peers behaviour and if you fail to copy your friends they classify you as being a coward. Outside the school, the sources of these problems are the internet and the social media like Facebook, whatsapp, imo and peer influence. What I have said are sources of the challenge in my opinion because students try to imitate how their role models behave in videos on social media and it reflects in their nick names in school. Students emulate the behaviours of their peers. For example, a form one student will try to emulate the behaviour of his school father. [45 year old, female teacher]

These interview comments clarify the issues on the sources of discipline problems. One of the themes that emerged under all the quotes is the influence of peers. The comments of the participants revealed that, most students engage in disciplinary problems due to the influence of their peers. Religious and cultural beliefs and culture influence are highlighted as sources of disciplinary problems among students in the school.

Bernice: To me, sources of these challenges are the home like irresponsible parenting and bad peers. Some parents don't care about how their wards behave, how they relate with their fellow siblings, talking anyhow to them whiles parents look on. Peers also are a source because they are always together therefore indiscipline students copy the behaviour from those they mingle with. [32 year old female teacher]

Eben: I think the sources of these acts come from varying sources including, peers, the media, religion and culture. The peers are a source because students of today love to mingle a lot with their peers. Whatever act their peers show makes them feel it's the best. So they end up cultivating such habits and they end up cultivating such bad habits. Examples of such act are alcoholism, the use of drugs, just to name a few. [40 year old male teacher] 


\subsection{Effects of disciplinary problems}

This section examines the data on the impact of disciplinary problems on teachers. The results are presented in Table 3.

Table 3: Effects of Disciplinary Problems on Teachers

\begin{tabular}{lll}
\hline Statements & Freq. & \% \\
\hline Create stress for teachers & 38 & 86 \\
Create a lack of sense of dignity at work & 40 & 91 \\
Causes teachers to feel depressed & 36 & 82 \\
Make teachers afraid for their safety & 44 & 100 \\
Teachers become demotivated & 44 & 100 \\
Cause teachers to have intense feelings of anger & 26 & 59 \\
\hline
\end{tabular}

Source: Field Data

From the table, student disciplinary issues have several effects on teachers. The results show that the areas where all $(100 \%)$ teachers agreed that disciplinary problems affected teachers were that it makes teachers afraid for their safety and that teachers become demotivated. This is followed by lack of sense of dignity at work $(91 \%)$, stress for teachers $(86 \%)$ and teachers to feel depressed (82\%). Where the least effect was reported was that disciplinary problems cause teachers to have intense feelings of anger $(59 \%)$. These results suggest that disciplinary problems can fundamentally affect teacher moral and working environment.

The quantitative data is further substantiated by some qualitative data that were gathered. Seven of the participants' comments are informative concerning the effects of disciplinary problem on teachers. Some of the teachers commented that:

Bernice: Because of students' attitude I even do not want to go to class but I am forced to go and teach because when supervisors come around they don't concentrate on the activity of the students however the teacher's competency and regularity in the classroom (a 32 year old female teacher).

Crabbe: Disciplinary challenges affect my morale as a teacher because sometimes I don't feel happy going to the technical classes to teach but we have been counseled not to look at the attitude of the students but to look at some of the good students as a source of motivation. The school counsellor counsels us from time to time (a 30 year old male teacher).

Other responses focused on the effects on school administration. A typical comment was as follows:

These challenge has an impact on my morale on my authority because, such vandalised items need to be refurnished and maintained in order to maintain a serene atmosphere. This goes a long way to affect the finance of the school. This creates pressure on me and the head master if there are injuries, the house masters are also stressed (Mia, a 51year old male teacher).

The comment raises two fundamental effects of student disciplinary problems. The first is that student disciplinary behaviours have impact on the moral of school authority. Teachers who have additional responsibilities as administrators get more stressed. This is more serious when disciplinary problems turn violent to include actions such as causing harm or vandalism. Looking for resources to repair or replace infrastructure which is destroyed during students' riot or vandalism which increases the budget of the school.

\subsection{Coping strategies of teachers in dealing with disciplinary problems}

This section was derived from the interviews. It was realised from the data thanishment was used as a major strategy to deal with disciplinary problems. Punishments have included strategies such as signing bonds of good behaviour and practical performances such as packing dining hall bowls, weeding or sweeping their classroom, internal suspension and external suspensions. Some of the specific comments of the respondents are indicated below:

Wegyir: We punish students sometimes. Punishments like packing dining hall bowls, weeding or sweeping their classroom. We have internal suspension and external suspensions. It is mostly after classes or when your service will be needed. The school authorities spell out the code of conduct for the students'body. Students are not made to partake in the making of the rules and regulations they are to follow, it is rather imposed on them. There is orientation at form one for students. Interpretations of the code of conduct are their warning. Rules and regulations are given by the GES. [45 year old, female teacher] 
Mia: Offences like truancy, bullying and stealing are punishable by suspension. The form ones are mostly the ones being bullied. It comes in the form of breaking into someone's chop box, and taking money from them forcefully, though some victims refuse to report to authorities, however, we are able to identify them through their own peers teasing them. If members of clans or groups are punished other members retaliate in the school sometimes too members secretly assist the victim in trying to carry out his or her punishment. The code of conduct for rules and regulations are given to students in the first year. It's done by GES. Students who act against school rules and regulations sometimes sign a bond of good behaviour in the school. (51year old male teacher).

Eben: The coping strategies we adopt to reduce such disciplinary acts are student's suspension that is either internal or external suspension, making some of them to weed large sizes of school lands, like the school field. The story I told you earlier on about my student who made me waste meaningful hours of my period was suspended externally for a week and when his suspension was over he was made to come to school with his parent and sign a bond of good behaviour. [40 year old Male teacher]

\section{Discussion}

The study revealed that truancy/lateness, dress code violation and disrespect for teachers were the major disciplinary problems experienced in Obuasi Secondary Technical School. These findings are line with the finding of Temitayo et al. (2013) that truancy and absenteeism are critical issues for every school. Many factors are responsible for students engaging truancy and absenteeism. Some of the factors include peer group influence and methods of teaching or discipline. Again, the leadership of the schools may be responsible for the truancy or absenteeism behaviour of the students.

The study revealed again that the major sources of disciplinary problems among students were poor economic background, bad parenting, peer pressure, student's inability to cope with the academic task, inappropriate handling of concerns of students by teachers and authorities and cultural influence. These findings are in line with Okumbe (2001) who found that discipline problems among students have their roots in the school, society and in the mind of students. Thus, the causes of indiscipline could be related to student's peculiarities, the social and family context, external influences and of social, economic, cultural, generational nature. Also, the findings agree with Farrant (2001) and Temitayo et al. (2013) who posited that even though most children receive the attention they need at home or in school in normal positive ways, some students feel that misbehaving in class or school is the best way to get attention. It appears that the lack of parental involvement is the major cause of disciplinary problems in secondary schools.

In addition, the study showed that indiscipline acts in schools had adverse impact on both academic and administration work. These findings are in support with Magwa and Ngara (2014) and Oliver (2011) who are of the view that when students misbehave they learn less and keep their peers from learning. This is because teaching contact time is reduced and more time is devoted to managing misbehaviour rather than teaching. Finn et al further asserted that this creates stress for teachers when they are detracted from academic time. This was supported by Bahru et al. (2009) that students' misconduct or misbehaviour in the classroom interferes with teaching and learning and is believed to be an antecedent to later school dropout and other similar negative social outcomes. Also, Noguera (2008) opined that ineffective classroom management and misbehaviour among students may create difficulties in providing high-quality teaching and learning opportunities.

Finally, the study revealed that punishment was used as a major strategy to deal with disciplinary problems. Punishments have included strategies such as signing bonds of good behaviour and practical performances such as packing dining hall bowls, weeding or sweeping their classroom, internal suspension and external suspensions. These strategies help students develop an understanding of society and their place in it that may lead to "acting out" behaviours deemed disruptive or counterproductive in schools (Ferguson, 2001; Eaton, 2010). These findings are in tandem with the findings of Skiba and Knesting (2001) who opined that the use of zero tolerance policies of punishing disciplinary problems is to ensure that the severe and rigid consequences will deter students from committing acts of severe indiscipline in schools.

\section{Conclusions}

According to the findings of this study, there exist various forms of indiscipline in the school. This means that both teachers and students agree to the fact that different acts of indiscipline are exhibited by the students contrary to rules and regulation of the school. Also, the students' and teachers' opinions with respect to the 
source of disciplinary problems that are predominant among students did not varied since they all agreed to same items as cause of disciplinary problem in the school. Again, in relation to the above findings, disciplinary problem in school has adverse on academic performance as well teacher morale towards teaching. Finally, the study conclude that appropriate measures can be put in place to cute the adverse effect of indiscipline on students' lifestyle as well as teachers' morale.

\section{Recommendations}

Following the findings of this study, the below recommendation were made:

1. Behaviour modification techniques should be employed to manage unruly behaviours of the students as alternative to expulsion and corporal punishments of different kind.

2. Each school should have a functioning disciplinary committee that sees to cases of indiscipline of students and which should be headed by a trained guidance counsellor.

3. A wholesome approach to manage students discipline should be adopted by all the school administrators and managers.

4. Each school should have a set of rules and regulations that will guide all actions and in actions of the students during school hours and should be constantly read to the hearing of all students.

\section{References}

Anderson, E. (1999). Code of the street: Decency, violence, and the moral life of the inner city. New York, NY: W. W. Norton.

Azizi, Y., Jamaludin, R., Shahrin, H., Mohd, A. I., Raja, R. R. A. R., \& Noordin, Y. (2009). Discipline problems among secondary school students in Johor Bahru, Malaysia. European Journal of Social Sciences, 11(4), $659-675$.

Bandura, A. (1977). Self-efficacy: Toward a unifying theory of behavioural change. Psychological Review, 84(2), 191-215.

Bandura, A. (1985). Model of causality in social learning theory. In A. Bandura (Ed.) Cognition and psychotherapy (pp. 81-99). Stanford University, CA: Springer.

Bandura, A. (1986). Social foundations of thought and action: A social cognitive theory. Englewood Cliffs, NJ: Prentice-Hall.

Barasa, M. M. (2013). Factors influencing drug abuse among students in public secondary schools in Mombasa District, Mombasa County, Kenya. Unpublished dissertation, University of Nairobi, Kenya.

Eaton, S. (2010). Beyond zero tolerance: Creating more inclusive schools by improving neighborhood conditions, attacking racial bias, and reducing inequality. In C. Edley, \& J. Ruiz de Velasco (Eds.), Changing places: How communities will improve the health of boys of colour (pp. 10-17). Berkeley, CA: University of California Press.

Farrant, J. S. (2001). Principles and practice of education. London: Longman.

Feldman, R. F. S. (1996). Understanding psychology (4 ${ }^{\text {th }}$ ed.). New York, NY: McGraw-Hill Inc.

Ferguson, A. A. (2001). Bad boys: Public schools in the making of black masculinity. Michigan: University of Michigan Press.

Ghana News Agency (GNA) (2007). Remain firm in enforcing discipline in schools-Vice president. Retrieved from https:/www.modernghana.com/blogs/150127/remain-firm-in-enforcing-discipline-in-schools-vicepresid.html

Ghana News Agency (GNA) (2016). CHASS advocates consultative forum on students' indiscipline. Retrieved from http:/www.myjoyonline.com/news/2016/september-18th/chass-advocates-consultative-forum-onstudents-indiscipline.php

Kiumi, J. K. (2012). Personal and school based factors as predictors of principals' inclusiveness in students' discipline management: the case of public secondary schools in Nyandarua and Laikipia Districts, Kenya. Universal Journal of Education and General Studies, 1(3), 049-054.

Mabeba, M. Z., \& Prinsloo, E. (2000). Perceptions of discipline and ensuing problems in secondary education. 
South African Journal of Education, 20(1), 34-41.

Magwa, S., \& Ngara, R. (2014). Learner indiscipline in schools. Review of Arts and Humanities, 3(2), 79-88.

Martin, R. E. (2004). Teachers' perceptions of behaviour problems in large schools. Research in Rural Education, 2, 105-111.

Marzano, R. J. (2007). The art and science of teaching: A comprehensive framework for effective instruction. Alexandria, VA: Association for Supervision and Curriculum Development.

Masekoameng, M. C. (2010). The impact of disciplinary problems on educator morale in secondary schools and implications for management. Unpublished master's thesis, University of South Africa, Pretoria, South Africa.

Matseke, J. B. (2008). Discipline in a secondary school at Winterveldt in North West Province. Unpublished master's thesis, Tshwane University of Technology, Pretoria.

McLeod, S. A. (2011). Albert Bandura-social learning theory. Retrieved from http://www.simplypsychology.org/bandura.html

Mokhele, P. R. (2006). The teacher-learner relationship in the m management of discipline in public high schools. Africa Education Review, 3(1 \& 2), 148-159.

Ngari, F. N. (2014). The influence of home based factors on students' discipline in secondary schools in Manyatta Division, Embu East District. Unpublished master's project, University of Nairobi.

Noguera, P. (2003). City schools and the American dream: Reclaiming the promise of public education. New York, NY: Teachers College Press.

Okumbe, J. A. (2001). Human resources management educational perspective. Nairobi: Educational Development and Research Bureau.

Onyechi, K. C., Okere, A., \& Trivellor, U. (2007). Deviant behaviour as correlate of academic achievement among secondary school adolescents: Implication of service delivery in the education sector-Issues and strategies. London: B. G. Mworugy.

Ouma, M. A., Simatwa, E. M., \& Serem, T. (2013). Management of pupil discipline in Kenya: A case study of Kisumu Municipality. Educational Research, 4(5), 2141-5161.

Polis, J., \& Upenieks, R., (2003). Peer education guidelines: HIV/AIDS and reproductive health. New York, NY: UNDP.

Rigby, K. (2000). Bullying in schools and what to do about it. London: Jessica Kingsley.

Rossouw. J. P. (2003). Learner discipline in South African public schools. South Africa: Koers.

Skiba, R. J., \& Knesting, K. (2001). Zero tolerance, zero evidence: An analysis of school disciplinary practice. In R. J. Skiba, \& G. G. Noam (Eds.), New directions for syouth development (pp. 11-17). San Francisco: Jossey-Bass.

Stewart, E. A., Schreck, C. J., \& Simons, R. L. (2006). "I ain’t gonna let no one disrespect me”: Does the code of the street reduce or increase violent victimization among African American adolescents? Journal of Research in Crime and Delinquency, 43, 427-458.

Temitayo, O., Nayaya, M. A., \& Lukman, A. A. (2013). Management of disciplinary problems in secondary schools: Jalingo metropolis in focus. Global Journal of Human Social Science, Linguistics and Education, 13(4), 7-19.

Thomas, M. (2005). Social learning theory: Lecture. Retrieved from http://www.innovativelearning.com/teaching/social_learning_theory.html

Zubaida, A. N. (2009): Indiscipline and its management techniques: A case study of a special education school in Kano State. The Journal of the National Council for Exceptional Children, 11(2), 455-463. 